\title{
Crowdfunding in Saudi Arabia: A Case Study of the Manafa Platform
}

\author{
Heba Gazzaz ${ }^{1}$ \\ ${ }^{1}$ King Abdulaziz University, Kingdom of Saudi Arabia \\ Correspondence: Heba Gazzaz, King Abdulaziz University, Kingdom of Saudi Arabia. E-mail: \\ hagazzaz@kau.edu.sa
}

Received: September 22, 2019

Accepted: October 29, 2019

Online Published: October 31, 2019

doi:10.5539/ijef.v11n11p72

URL: https://doi.org/10.5539/ijef.v11n11p72

\begin{abstract}
Crowdfunding is an innovative form of financial support that is increasingly used around the world. Crowdfunding can provide a new investment channel and help those with innovative ideas and start-up businesses to circumvent traditional financing struggles and secure alternative finance. This paper presents an overview of crowdfunding, its fundamentals, and its main participants. Specifically, it explores the characteristics of crowdfunding in Saudi Arabia by examining the first and successful crowdfunding platform (Manafa) to be licensed by the country's capital market authority. This paper shows that the sole applicable model in Saudi Arabia is equity-based crowdfunding, and this is significantly controlled and operated under a more efficient legal framework than much foreign crowdfunding. However, the Saudi market would benefit from greater awareness of crowdfunding as a new investment channel, and from the introduction of the debt-based crowdfunding model in accordance with Saudi market regulations.
\end{abstract}

Keywords: Crowdfunding, capital market authority (CMA), fintech, SMEs, Manafa

\section{Introduction}

The launch of a parallel equity market (Numo) as a platform for small and medium-sized companies (SMEs) was aligned with key goals of the Saudi Vision 2030. By the year 2030, the national plan aims to increase SMEs' contribution to GDP from $20 \%$ to $35 \%$ (Note 1). However, it is not easy for SMEs to satisfy the listing requirements for Numo for several reasons. For example, Numo is restricted to qualified and accredited investors only, the proportion of shares to be owned by the public must be no less than $20 \%$, and market value of businesses must be at least 10 million Saudi Riyals.

The new and innovative technology-based financing tool called crowdfunding can sometimes respond better to the needs and gaps in current arrangements for the funding of entrepreneurial enterprise than the services currently provided by conventional financing methods such as venture capitalists, angel investors, and banks (Christensen, 2013). Crowdfunding operates by raising via the internet a small amount of money from a wide range of individuals, and each offering runs for a specific period of time in order to achieve the required amount of money.

Claims that crowdfunding is rapidly becoming the main source of start-up funding are supported by a significant body of literature. Almost $\$ 1.5$ billion was raised in 2011 from more than 1 million crowdfunding campaigns. In 2012 the value of the UK crowdfunding market was estimated at \$303 million. Collective finance companies managed to raise $\$ 16.2$ billion in 2014, and the World Bank expects collective finance companies to raise $\$ 96$ billion in 2025. See (Davis, 2012; Hollas, 2013; Manchanda \& Muralidharan, 2014; Crowdfunding Industry Report, 2012).

Additionally, and according to an International Monetary Fund (IMF) report published in 2012, the collective financing opportunities in developing countries are larger than those of developed countries. The crowdfunding market in Saudi Arabia is expected to reach more than 4.4 billion Saudi Riyals in the next few years, according to World Bank estimates. The capital markets are still, in many aspects, working to rules and regulations developed for the financial capital markets in Saudi Arabia, with the primary objective being to satisfy the goals of Saudi Arabia Vision 2030, in which SMEs have a strong role in the growth of Saudi Arabia's economy.

The capital market authority (CMA) in Saudi Arabia has identified a need to diversify investment channels and decentralise funding from traditional sources, thereby triggering an increase in GDP and a reduction in the unemployment rate while realizing the Saudi Arabian vision for 2030. The CMA, therefore, adopted an initiative 
called the financial technology laboratory, to develop the financial sector and exploit financial technology for the benefit of financial markets. In July 2018, the CMA gave each of two companies a financial, technical experience permit, which allows them to test the collective funding model. Those companies are called Manafa Capital and Scopeer. The CMA is currently studying applications for other permits.

As far as this author is aware, this is the first paper on crowdfunding in Saudi Arabia to provide an overview of crowdfunding fundamentals and discuss the characteristics of crowdfunding in Saudi Arabia by examining the country's first crowdfunding platform, Manafa.

\section{Literature Review}

Crowdfunding is expressed as an effort where a huge amount of business capital is collected from few investors, while interested parties in the business are connected through the internet (Danmayr, 2013; Piliyanti, 2019). Hope and Vyas (2017) argued that crowdfunding enables firms to obtain external finances and funds required at the inception of the project. Various studies indicate that it serves as a great advantage to the Small and Medium Enterprises (SMEs) as bank lending is decreased as a result of financial disruptions (Andrieş \& Ursu, 2016; Martínez-Climent, Zorio-Grima, \& Ribeiro-Soriano, 2018). For instance, Wahjono, Marina, and Widayat (2016) highlights that crowdfunding is particularly useful for SME as bank rejects more than half of the SME credit applications, whereas, for larger companies, its rejection rate is only 7 percent. Recurrent use of crowdfunding is superseding the conventional means of obtaining funds, which provided the initial capital to a venture. Belleflamme et al. (2014), based on these characteristics, states crowdfunding as a crowdsourcing subset and simultaneously recognizing these as the Fintech subset.

The crowdfunding cycle (ecosystem) represents the relationships between the main three parties involved in the crowdfunding process: entrepreneurs, investors, and website providers (intermediaries). The existence of a crowdfunding platform is significant to entrepreneurs for several reasons (Beaulieu, Sarker, \& Sarker, 2015). The ease of access such platforms permit allows entrepreneurs to post a description of their idea or project online at a crowdfunding site, and thus to expose that idea to a large number of potential investors, all at once (Gerber et al., 2012; Khan \& Baarmah, 2017; Ramsey, 2012). If a group of individual believes in the idea, they will contribute a small amount of money to help support the project (Wojciechowski, 2009). Thus, the crowdfunding aspect enhances the community based on sharing a common interest and social connections (Colombo et al., 2015; Kim et al., 2008). This contrasts strongly with other, more traditional forms of finance, where the entrepreneur proposes his/her idea several times and individually to a very limited number of potential investors, such as venture capitalists or bank fund managers.

Crowdfunding offers significant support and services for entrepreneurs. It provides pre-sale market research and marketing strategies (word of mouth), which are among the essential requirements for a start-up (Ordanini et al., 2011). Crowdfunding services allow entrepreneurs to examine the project's feasibility and get crowd feedback or wisdom with no additional cost. Moreover, even the traditional capital markets may look to crowdfunding as a value-added step, i.e., traditional capital markets can support the founders once they have succeeded (Burns, 2013). So, they can use crowdfunding websites to verify whether a market exists and to explore different price points. Thus, crowdfunding has enlarged the market (Cumming \& Johan, 2013). Khan and Baarmah (2017) highlights that crowdfunding has advanced the emergence of creative platforms where various platforms reach out to entrepreneurial brands to facilitate their business operations. Several studies affirm that aspect of crowdfunding should not only be viewed from a financial perspective but also as a process that leads to the formation of innovative business models for entrepreneurs (Bendickson et al., 2017; Iršič 2017; Lehner et al., 2015; Orlandi 2017). El Talla et al. (2018) stated that crowdfunding provides substantial benefits to the entrepreneurs and help progress the creative aspects in the entrepreneurial setting. Such as Davis et al. (2017) study on ten different pilot projects showed that the innovative aspect of the platform promotes the investors to finance different projects. It also revealed that the entrepreneurial enthusiasm drives investors' sympathy and indirectly promotes them for project financing.

There are several factors affecting the level of crowdfunding success such as the nature of project (Agrawal et al., 2011; Pitschner \& Pitschner-Finn, 2014), the functional distance between participants (Agrawal et al., 2011; Giudici et al., 2013), project duration (Cordova et al., 2015), the cultural differentiation between entrepreneurs and contributors (Burtch et al., 2013). Moreover, Pitschner and Pitschner-Finn (2014) argued that considering more sociological and psychological concepts in crowdfunding activity is crucial as any individual can be a potential contributor and their behaviour can affect the success of the crowdfunding campaign (Macht \& Weatherston, 2014). Accordingly, (Rodriguez-Ricardo et al., 2018) examine innovativeness, attitudes toward supporting each other and interpersonal connectivity as determinants of consumers' intention to participate in the 
crowdfunding process. The results show that both social identifications with the crowdfunding community and innovativeness have a positive effect on the intention to participate.Morover, Anglin et al. (2018) on Kickstarter showed that the use of positive language and words increase the prospects of the success of the campaign. Another research by Blakely et al. (2016) showed that effective and creative pitches are more likely to attain crowdfunding success. It reflected that positive psychological capital experience is likely to improve fundraising quality and performance. Other factors that impact the success of the financial plan include the clear exit strategy, financial plan existence (Ahlers et al., 2015). Most studies highlight that the success of the crowdfunding plan includes an understanding of the investors' characteristics (Cholakova \& Clarysse, 2014; Gerber et al., 2012; Ordanini et al., 2011).

The crowdfunding process relies heavily on technology, for example in terms of the websites used to propose an idea to a wide range of potential investors, and social media connections that can be used to research projects and the entrepreneur(s) involved and facilitated communication between the borrower and lender involve and thus conduct a decision whether to invest or not and finally to provide a third party to secures the payment process. In other words, they act as a middle man or intermediary (Ordanini, Miceli, Pizzetti, \& Parasuraman, 2011). Contributors to crowdfunding projects may feel one, or a combination of several, motivations, such as a positive feeling associated with helping others to make their dreams come true, and a sense of being selfless (Burtch, Ghose, \& Wattal, 2013). Alternatively, they may simply want to be part of the project such as personal loans, medical expense solutions, publishing and printing (Gerber et al., 2012) or want to receive a return on their investment.

Globally, there various drivers to use crowdfunding. The reward in which the investors gain in return from making a monetary contribution to support the entrepreneur is a key distinguishing feature of the various crowdfunding models: equity-based crowdfunding, debt-based crowdfunding, reward-based crowdfunding and donation-based crowdfunding (Ordanini et al., 2011). Equity-based crowdfunding occurs when the investor receives partial ownership of an interest in the firm and thus becomes entitled to a dividend. As with any firm at the development and growth stage in its life cycle, with a higher growth rate, the payout ratio would be low to the point of approaching zero because the firm needs to keep all profit as retained earnings in order to expand. Nevertheless, the firm must prove its growth and value to the investors by retaining less of its earnings and paying a good cash dividend (Hauser \& Thornton Jr, 2012). Therefore, the distribution of profits during the first few years of operation is unlikely in start-up firms with a high growth rate.

Reward-based crowdfunding is where entrepreneurs give a copy of the product or a souvenir from the project, for example, a t-shirt, an invitation to a special event, and keychain, but offer no interest or profit to investors. Debt-based crowdfunding is when the borrowers intend to return the money invested money by contributors, who are entitled to receive an interest payment. Finally, donation-based crowdfunding is where the appreciation (thank you) is the only reward for the monetary contribution paid by the investor, who will receive no cash return. Figure 1 shows the various crowdfunding models.

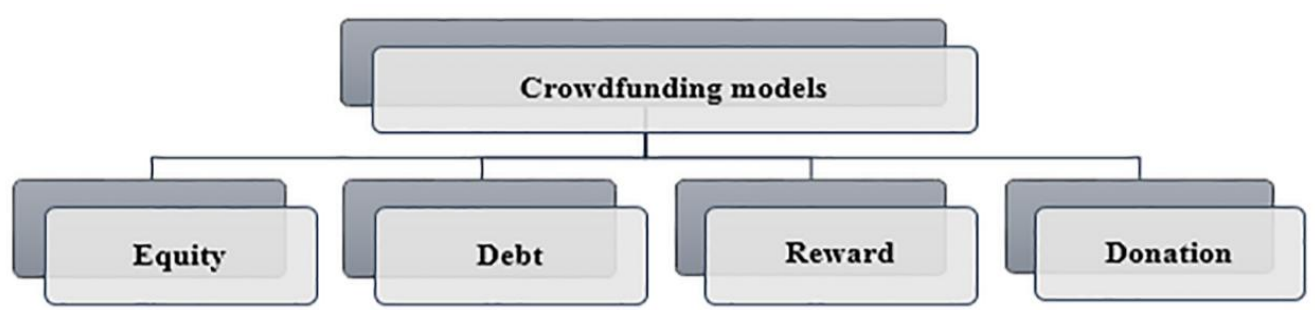

Figure 1. Crowdfunding models

However, the different types of crowdfunding are not devoid of risk. Such as Kirby and Worner's (2014) study stated that the risk of default, non-payment, closing, or platform failure continues to persist across different crowdfunding platforms. Other risks identified include liquidity risk, fraud, cyberattack, and lack of transparency (Kirby \& Worner, 2014). Schwartz (2012) stresses that crowdfunding is not devoid of regulatory mechanism where different laws and procedures are required for electronic money exchange and transfer, either by credit cards or electronic prepaid cards, i.e., Paypal, Mobile Phone, CashU and more. This allows the government to regulate the activities and control different finance laundering as well as terrorist financing operations. Similarly, Deffains-Crapsky and Sudolska (2014) established the effectiveness and significance of crowdfunding for entrepreneurial innovations, emphasizing the need to introduce structured laws for safeguarding the investors 
against fraudulent activities. Another study by Sharma and Lertnuwat (2016) stated crowdfunding as an alternative to the financing of different business models. It showed that these platforms are heavily invested, which can drive the number of projects up and would require more regulatory control.

Every year, millions of start-ups pursue success and profit, but unfortunately, most fail. This failure can be caused by numerous factors such as lack of planning, experience, reliance on debt, and lack of capital funding. Experience plays a significant role in mitigating the risk of crowdfunding. The entrepreneurs' experience varies but tends to fall into or between two categories of experience: business experience and product experience. Business experience is an experience gained from previous business; such people have experience of how to deal with obstacles in a start-up. Product experience is gained from developing and marketing the product. Start-up founders can be rich in both kinds of experience or lacking in both or in one of them.

\section{Methodology}

An exploratory research design is adopted following a case study approach. It is selected as it helps in a comprehensive and extensive analysis of the case and its related activities (Lam \& Law, 2016). The primary motive of this research is to assess the crowdfunding growth in Saudi Arabia, precisely for Manafa. The case of Manafa is selected due to its proven success for attaining the maximum investment limit as proposed. The study, thereby, provides a profound analysis of the work relevant to the crowdfunding in Saudi Arabia. It reviews the practices of Manafa and the crowdfunding activities undergone. All the information available from the authentic sources and official websites are used for the analysis.

\section{Analysis and Discussion}

Saudi Arabia has a rapidly growing and developing an economy where, according to world development indicators (World Bank Group, 2016), the youth dependency ratio is more than $40 \%$. This indicates an ability to become economically independent, with high potential for innovation and creativity. However, about $92 \%$ of SMEs in Saudi Arabia face obstacles in securing the funds required for their ventures (Parveen et al., 2017). Saudi Arabia's Vision 2030 foregrounds the contribution that SMEs can make to the growth and diversification of the economy. Therefore, the Saudi government launched a venture investment initiative comprising three programs. Currently, the only activated program is the start-up investment program, which brings together the general authority for SMEs (Monshaat) (Note 2) and various crowdfunding platforms, incubators, and accelerators such as Manafa, Wadi Jeddah Ventures, and Saudi Aramco Entrepreneurship Center. The intention is for these bodies to cover the current funding gaps of emerging businesses and to increase the productivity of such enterprises. Crowdfunding is providing a new investment channel with good returns, and for investors, this serves to diversify investment opportunities and reduce the overall risk levels of an investment portfolio. A significant body of the literature agrees that crowdfunding generally fills a gap in start-up financing, and gives investors opportunities to invest in companies on a crowdfunding platform.

The only crowdfunding model applicable in the Saudi financial marketplace is the equity crowdfunding model. This is because the experimental permits granted by the CMA to crowdfunding firms must, as well as finding the best-fit model for the Saudi market, meet its regulatory requirements, which are based on Sharia (Islamic) codes. In order to examine the success of crowdfunding campaigns (Beaulieu et al., 2015) argued that there are two ways to quantify success in crowdfunding. The first is to satisfy the maximum limit, which means that people believe in the entrepreneur's idea. (Belleflamme et al., 2016) found a positive relationship between the number of contributors and the probability of funding the project successfully. The second lies in the ability to survive and distribute profits to investors, as would be expected from investment in high-risk projects.

In Saudi Arabia, there are two authorised crowdfunding platforms, but only one of these - Manafa - has proven successful because it has satisfied the maximum limit for all proposed investments. The Scopeer platform, unfortunately, did not succeed in satisfying the maximum limit for all proposed investments. However, until now, none of the SMEs funded through Manafa has distributed any dividends, due to their high growth rate. Thus far, Manafa has yielded four successful campaigns and is now considering more and diversified investment opportunities. However, the four campaigns in question sought funds to expand an already existing business, not a start-up, which substantially minimised the risk. 
Table 1 . Successful equity crowdfunding campaigns conducted via Manafa

\begin{tabular}{lcccc}
\hline & Albait & Flicron & Esracabin & Which \\
\cline { 2 - 5 } Market value & $9,157,500$ & $3,150,000$ & $6,650,000$ & $9,000,000$ \\
\hline Offer price & 24.75 & 42 & 19 & 180 \\
No. of shares ex-ante the offering & 370,000 & 75,000 & 350,000 & 50,000 \\
No. of shares ex-post the offering & 528,566 & 86,905 & 613,157 & 66,667 \\
Number of the issued shares & 158,566 & 11,905 & 263,157 & 16,667 \\
Amount of funding raised & $3,926,736$ & 500,010 & $4,999,983$ & $3,000,060$ \\
Ownership percentage & $30 \%$ & $13.7 \%$ & $43 \%$ & $25 \%$ \\
Min limit for all investors & $1,014.75$ & 1,008 & 1,007 & 1,080 \\
Max limit for immature investors & 19,998 & 19,992 & 19,988 & 19,980 \\
Offering period & 1 day & 10 minutes & 23 days & 80 days \\
\hline
\end{tabular}

Table 1 reports the main aspects of the shares offering for the four campaigns successfully funded via Manafa. Market value is equal to the offer price multiplied by the number of shares ex-ante the offering. In the Saudi market, the valuation must be made through the Saudi authority for accredited valuers (TAQEEM), who apply international valuation standards to increase community trust and awareness in the valuation profession.

Previous studies have argued that setting the market value of the start-up before the crowdfunding campaign starts can be inefficient (overvalued/undervalued) due to the difficulty of estimating some parts of the business. To circumvent this, Manafa allows a specified number of shares during the campaign and requires accredited valuers to evaluate the start-up firm. The offer price is the price at which a company is offering the issued shares to the contributors. The amount of funding raised is the offer price multiplied by the number of issued shares. Ownership percentage is the percentage of the number of shares ex-post the offering owned by the contributors. Finally, the offering period is the period of time needed to satisfy the maximum limit (i.e., for the funds required to be raised).

There are two approaches to determining the level of risk in each of the crowdfunding models. In the first approach, in which the size of the firm is used in determining the level of risk, a larger size leads to more complicity, and that will cause an increase in the risk level. The second approach uses the amount of contribution to determine the level of risk. When the contributor invests a small amount of their money in a start-up firm, the risk will be less - and vice versa (Beaulieu et al., 2015).

Table 1 shows that the market value for each of the four SMEs is below 10 million Saudi Riyals, which means that the funds required can be raised only through the Manafa website, and not through the parallel Saudi market, Numo. In order to be listed on Numo, the market value of SMEs must be 10 million Saudi Riyals or more.

Numo allows qualified foreign investors according to the rules for qualified foreign financial institutions investment in listed securities. However, Manafa allows only national investors, whether qualified or unqualified. This is to hedge against the risks of global investment such as currency, political concerns, language, tax, and foreign countries' regulations. Manafa is regulated differently from Numo and allows offerings to non-accredited investors.

From the investor's perspective, start-up firms are a highly risky investment and to lower this risk, the CMA sets a minimum limit for all types of investor. For financial institutions, professional or beginner investors this is 1000 Saudi Riyals per investment opportunity. The maximum limit for all types of investor, among five investment opportunities, is 100,000 Saudi Riyals. This benefits investors because it provides an opportunity to increase the diversity of their investment portfolio.

Thus, for the four cases studied here, the minimum amount for all investors was around 1000 due to the offer price, i.e.; Albait (1015), Flicron (1008), Esracabin (1007) and Which (1080), as shown in Table 1. However, Manafa set a maximum limit of 20,000 Saudi Riyals in each investment opportunity for novice investors, while for the financial institutions and professional investors, no limit per investment opportunity was set, to reduce the risk in already highly risky investments.

Moreover, investment in the Manafa crowdfunding platform starts at 1000 Saudi Riyals, while in venture capital, it starts at 375,000 Saudi Riyals. With Manafa, the investment decisions are made by the investors independently; the crowdfunding platform facilitates and ensures the validity of information shown through their platform.

In contrast, the venture capital fund manager makes all of the investment decisions. When raising funds through a crowdfunding platform, the entrepreneur shares no profit, while the venture capital fund manager will 
generally receive from 1 to $3 \%$ of the profit (Manafa, 2019).

According to CMA, the time period for raising the required funds via the accredited website (Manafa) is either 80 days or whenever contributors have pledged the required amount of funding. Surprisingly, in practice, we observed that the time period between the announcement of the campaign and reaching the maximum limit was between 10 minutes and 80 days. Albait was the first investment opportunity on Manafa and the offer period was 80 days, due to the newness of the investment channel. Meanwhile, Filcron took only 10 minutes to reach the maximum limit, which suggests that most of the investors were irrational and immature in terms of investment experience. Financial information is only made available at the date from which investment is open, and these investors' hasty response suggests they could not have read the financial documentation thoroughly. Equity crowdfunding is risky, due to information asymmetries and limited data being available in the public domain. As things stand, many merely gamble and so increase the already elevated level of risk surround SMEs. Publishing such relevant information before the campaign begins would increase the trust in crowdfunding platforms as well as the project itself because the investors would have sufficient time to analyse and give feedback to the entrepreneur.

Venture capital tends to invest in the technology sector more than any other industry; such investors are less keen to invest in product and service sectors (Hollas, 2013; Manchanda \& Muralidharan, 2014). Investing in the technology sector is highly risky, and the firms are less likely to survive. In Saudi Arabia, half of all successful crowdfunding campaigns are in the technology sector, which serves to increase the already high risk associated with crowdfunding as an alternative funding channel. According to the literature, it would be better to diversify the range of sectors, since diversification among sectors would mitigate the overall risk.

Collective financing faces many challenges and risks, which mostly relates to ethical issues pertaining to the crowdfunding models. Entrepreneurs deserve legal protection to prevent their innovative ideas from being stolen or used by other firms. On the other side, the contributors need legal protection against the borrower, should they fail to perform as expected (Masnick, 2014). In the USA in 2012, the lawmakers and regulators passed the Jumpstart Our Business Startups Act (JOBS ACT) to encourage funding for SMEs. However, previous studies have shown that there is still a significant concern, and have recommended further regulation of the crowdfunding process through a balancing of protection for investors with facilitation of the entrepreneurs' activities.

Increasing the number of crowdfunding platforms would increase the competition between them, so the ability to detect fraud would become a means of differentiation. Many experts have predicted that crowdfunding would grow most quickly in developing countries, where the entrepreneurs lack access to traditional financing. Instead, crowdfunding has grown more quickly in the developed world than in emerging markets, and this has been due to the quality of regulation, corruption control, levels of trust between investors and entrepreneurs and the ease with which it is possible to do business in a country. All of these are key factors in boosting crowdfunding volumes (Rau, 2108).

In January 2018, the CMA issued financial technology experimental permit instructions to provide a regulatory framework that is conducive to the innovation of financial technology ('FinTech') in the capital market within the Kingdom of Saudi Arabia. Companies apply for the permit in order to participate in the FinTech lab, and when the company is approved by the CMA, that approval ensures legal protection from fraud cases.

The FinTech ex permit is not intended to create a risk-free FinTech environment. Rather, it aims to promote FinTech innovation in a controlled environment, within which the consequences of failure can be contained.

The CMA requires SMEs to be closed joint companies before a crowdfunding campaign can begin, in order to be under the Saudi company law and hedge against legal risks. The company law that governs joint-stock companies and offers a good standard of governance for this type, such as separation between the ownership and the management of the company, and mandatory disclosure and transparency (Note 3). This would ensure the validity of the investment process, as all of the regulations and protection policies in the Saudi financial market will be applied.

Moreover, the crowdfunding platform (Manafa) takes three months to conduct due diligence checks via the Bayan Credit Bureau, which has been authorised by the Saudi Arabia Monetary Authority to evaluate firms through the Saudi authority for accredited valuers (TAQEEM) to increase the community's trust in and awareness of the investment opportunities proposed via Manafa.

Finally, the characteristics of the closed joint companies on crowdfunding platforms are similar to those of the listed joint companies on Tadawul and Numo. Those characteristics include a pre-emptive right that offers 
existing shareholders the right to buy new shares and voting rights that allow the investors one vote per share.

\section{Acknowledgements}

The author is very grateful to all the associated personnel in any reference that contributed in/for the purpose of this research. Further, this research holds no conflict of interest and is not funded through any source.

\section{References}

Agrawal, A., Catalini, C., \& Goldfarb, A. (2011). The geography of crowdfunding. SSRN Electronic Journal, 1-57. https://doi.org/10.3386/w16820

Ahlers, G. K., Cumming, D., Günther, C., \& Schweizer, D. (2015). Signaling in equity crowdfunding. Entrepreneurship theory and practice, 39(4), 955-980.

Andrieș, A. M., \& Ursu, S. G. (2016). Financial crisis and bank efficiency: An empirical study of European banks. Economic research-Ekonomska istraživanja, 29(1), 485-497. https://doi.org/10.1080/1331677x.2016.1175725

Anglin, A. H., Wolfe, M. T., Short, J. C., McKenny, A. F., \& Pidduck, R. J. (2018). Narcissistic rhetoric and crowdfunding performance: A social role theory perspective. Journal of Business Venturing, 33(6), 780-812. https://doi.org/10.1016/j.jbusvent.2018.04.004

Beaulieu, T., Sarker, S., \& Sarker, S. (2015). A conceptual framework for understanding crowdfunding. Communications of the Association for Information Systems, 37. https://doi.org/10.17705/1cais.03701

Belleflamme, P., Omrani, N., \& Peitz, M. (2016). Understanding the strategies of crowdfunding platforms. CESifo DICE Report, 14(2), 6-10. http://hdl.handle.net/10419/167257

Bendickson, J., Muldoon, J., Liguori, E., \& Midgett, C. (2017). High performance work systems: A necessity for startups. Journal of Small Business Strategy.

Biancone, P. P., Secinaro, S., \& Kamal, M. (2019). Crowdfunding and Fintech: Business model sharia compliant. European Journal of Islamic Finance, (12).

Burns, M. (2013). Pebble nabs $\$ 15 M$ in funding, outs Pebblekit SDK and Pebble Sports API to spur smart watch app development. Retrieved from https://techcrunch.com/2013/05/16/pebble-nabs-15m-in-funding-outs-pebblekit-sdk-and-pebble-sports-api-t o-spur-smartwatch-app-development/

Burtch, G., Ghose, A., \& Wattal, S. (2013). An empirical examination of the antecedents and consequences of contribution patterns in crowd-funded markets. Information Systems Research, 24(3), 499-519. https://doi.org/10.1287/isre.1120.0468

Calic, G., \& Mosakowski, E. (2016). Kicking off social entrepreneurship: How a sustainability orientation influences crowdfunding success. Journal of Management Studies, 53(5), 738-767. https://doi.org/10.1111/joms.12201

Cholakova, M., \& Clarysse, B. (2015). Does the Possibility to Make Equity Investments in Crowdfunding Projects Crowd Out Reward-Based Investments? Entrepreneurship Theory and Practice, 39(1), 145-172. https://doi.org/10.1111/etap.12139

Christensen, C. (2013). The innovator's dilemma: When new technologies cause great firms to fail. Boston, MA: Harvard Business Review Press.

Colombo, M. G., Franzoni, C., \& Rossi-Lamastra, C. (2015). Internal social capital and the attraction of early contributions in crowdfunding. Entrepreneurship Theory and Practice, 39(1), 75-100. https://doi.org/10.1111/etap.12118

Cordova, A., Dolci, J., \& Gianfrate, G. (2015). The determinants of crowdfunding success: Evidence from technology projects. Procedia - Social and Behavioral Sciences, 181, 115-124. https://doi.org/10.1016/j.sbspro.2015.04.872

Cumming, D., \& Johan, S. (2013). Demand-driven securities regulation: evidence from crowdfunding. Venture Capital, 15(4), 361-379. https://doi.org/10.1080/13691066.2013.847635

Danmayr, F. (2013). Archetypes of crowdfunding platforms: A multidimensional comparison. Springer Science \& Business Media. https://doi.org/10.1007/978-3-658-04559-3_2

Davis, A. (2012). Beyond the banks. Innovative ways to finance Britain's small businesses. London: NESTA 
Davis, B. C., Hmieleski, K. M., Webb, J. W., \& Coombs, J. E. (2017). Funders' positive affective reactions to entrepreneurs' crowdfunding pitches: The influence of perceived product creativity and entrepreneurial passion. Journal of Business Venturing, 32(1), 90-106. https://doi.org/10.1016/j.jbusvent.2016.10.006

Deffains-Crapsky, C., \& Sudolska, A. (2014). Radical innovation and early stage financing gaps: Equity-based crowdfunding challenges. Journal of Positive Management, 5(2), 3-19. https://doi.org/10.12775/jpm.2014.009

El Talla, S. A., Al Shobaki, M. J., Abu-Naser, S. S., \& Amuna, Y. M. A. (2018). Crowdfunding Role in Boosting the Entrepreneurial Creativity of University Students.

Gelfond, S. H., \& Foti, A. D. (2012). US $\$ 500$ and a click: Investing the "crowdfunding" way. Journal of Investment Compliance, 13(4), 9-13. https://doi.org/10.1108/15285811211284074

Gerber, E. M., Hui, J. S., \& Kuo, P. Y. (2012, February). Crowdfunding: Why people are motivated to post and fund projects on crowdfunding platforms. In Proceedings of the International Workshop on Design, Influence, and Social Technologies: Techniques, Impacts and Ethics (Vol. 2, No. 11, p. 10). Northwestern University Evanston, IL.

Giudici, G., Guerini, M., \& Rossi-Lamastra, C. (2013). Why crowdfunding projects can succeed: The role of proponent's individual and territorial social Capital. SSRN Electronic Journal, 1-20. http://dx.doi.org/10.2139/ssrn.2255944

Hope, O. K., \& Vyas, D. (2017). Private company finance and financial reporting. Accounting and Business Research, 47(5), 506-537. https://doi.org/10.1080/00014788.2017.1303963

Iršič, M. (2017). The effect of adaptation and trust on positional advantage of companies in B2B relationships: The moderating role of relationship value. Economic research-Ekonomska istraživanja, 30(1), 76-90. https://doi.org/10.1080/1331677x.2017.1305781

Khan, M. R., \& Baarmah, J. M. (2017). Building a case for crowdfunding platforms in Saudi Arabia. Middle East Journal of Entrepreneurship, Leadership and Sustainable Development, 1(1), 43-60.

Kim, D., Ferrin, D., \& Raghav, R. (2008). A trust-based consumer decision-making model in electronic commerce: The role of trust, perceived risk, and their antecedents. Decision Support Systems, 44(2), 544-564. https://doi.org/10.1016/j.dss.2007.07.001

Kirby, E., \& Worner, S. (2014). Crowd-funding: An infant industry growing fast. IOSCO Research Department.

Knight, T. B., Leo, H., \& Ohmer, A. (2012). A very quiet revolution: A primer on securities crowdfunding and title of the JOBS act. Michigan Journal of Private Equity \& Venture Capital Law, 2(1), 135-153.

Koning, R., \& Model, J. (2013). Experimental study of crowdfunding cascades: When nothing is better than $\begin{array}{llllll}\text { something. Academy of } & \text { Management } & \text { Proceedings, } & 1, & 16683 .\end{array}$ https://doi.org/10.5465/ambpp.2014.16683abstract

Kuppuswamy, V., \& Bayus, B. L. (2014). Crowdfunding creative ideas: The dynamics of project backers in Kickstarter. SSRN Working Paper. https://doi.org/10.2139/ssrn.2234765

Lam, P. T., \& Law, A. O. (2016). Crowdfunding for renewable and sustainable energy projects: An exploratory case study approach. Renewable and Sustainable Energy Reviews, 60, 11-20. https://doi.org/10.1016/j.rser.2016.01.046

Lehner, O. M., Grabmann, E., \& Ennsgraber, C. (2015). Entrepreneurial implications of crowdfunding as alternative funding source for innovations. Venture Capital, 17(1-2), 171-189. https://doi.org/10.1080/13691066.2015.1037132

Macht, S. A., \& Weatherston, J. (2014). The benefits of online crowdfunding for fund-seeking business ventures. Strategic Change, 23(1-2), 1-14. https://doi.org/10.1002/jsc.1955

Macht, S.A. \& Weatherston, J. (2014). Competitive paradigms on strategic change: Mapping the field and further research development. Strategic Change, 15(3), 129-144. https://doi.org/10.1002/jsc.758

Martínez-Climent, C., Zorio-Grima, A., \& Ribeiro-Soriano, D. (2018). Financial return crowdfunding: literature review and bibliometric analysis. International Entrepreneurship and Management Journal, 14(3), 527-553. https://doi.org/10.1007/s11365-018-0511-x

Mollick, E. (2014). The dynamics of crowdfunding: An exploratory study. Journal of Business Venturing, 29(1), 1-16. https://doi.org/10.1016/j.jbusvent.2013.06.005 
Ordanini, A., Miceli, L., Pizzetti, M., \& Parasuraman, A. (2011). Crowd-funding: Transforming customers into investors through innovative service platforms. Journal of Service Management, 22(4), 443-470. https://doi.org/10.1108/09564231111155079

Orlandi, L. B. (2017). Am I an entrepreneur? Identity struggle in the contemporary women entrepreneurship discourse. Contemporary Economics, 11(4), 487-498.

Parveen, M., Maimani, K., \& Javiad, S. (2017). An experimental study of Saudi entrepreneurs who owned small and medium enterprises in Saudi Arabia. International Review of Management and Business Research, 6(1), 257-273.

Piliyanti, I. (2019). Fintech Achieving Sustainable Development: The Side Perspective of Crowdfunding Platform. Shirkah: Journal of Economics and Business, 3(2). https://doi.org/10.22515/shirkah.v3i2.207

Pitschner, S., \& Pitschner-Finn, S. (2014). Non-profit differentials in crowd-based financing: Evidence from50,000 campaigns. Economics Letters, 123(3), 391-394. https://doi.org/10.1016/j.econlet.2014.03.022

Ramsey, Y. A. (2012). What the heck is crowdfunding. Business people, 25(11), 54-57.

Rodriguez-Ricardo, Y., Sicilia, M., \& López, M. (2018). What drives crowdfunding participation? The influence of personal and social traits. Spanish Journal of Marketing - ESIC, 22(2), 163-182. https://doi.org/10.1108/SJME-03-2018-004

Schwartz, A. A. (2012). Crowdfunding securities. Notre Dame L. Rev., 88, 1457.

Sharma, S., \& Lertnuwat, N. (2016). The financial crowdfunding with diverse business models. Journal of Asian and African Social Science and Humanities, 2(2), 74-89.

Small and Medium Enterprises Report. (2016). Small and Medium Enterprises Report April, 2016. Retrieved from https://www.jeg.org.sa/sites/default/files/library/files/SME-EN.pdf

Vismara, S. (2015). Information cascades among investors in equity crowdfunding. SSRN working paper. https://doi.org/10.2139/ssrn.2589619

Wahjono, S. I., Marina, A., \& Widayat, M. (2016). Critical Analysis Of Crowdfunding To Finance Smes In Muslim Countries. Balance, 13(01).

Wojciechowski, A. (2009). Models of charity donations and project funding in social networks. OTM 2009 Workshops on the Move to Meaningful Internet Systems, 454-463. https://doi.org/10.1007/978-3-642-05290-3_58

Younkin, P., \& Kashkooli, K. (2013). A crowd or a community? Comparing three explanations for the decision to donate to a crowdfunding project. Retrieved from https://www.funginstitute.berkeley.edu/sites/default/files/A_Crowd_Or_Community.pdf.

Zvilichovsky, D., Inbar, Y., \& Barzilay, O. (2013). Playing both sides of the market: Success and reciprocity on crowdfunding platforms. SSRN Working Paper. https://doi.org/10.2139/ssrn.2304101

\section{Notes}

Note 1. https://vision2030.gov.sa/download/file/fid/417

Note 2. The General Authority for Small and Medium Enterprises (Monshaat) was established in 2016 to formulate, advocate and develop the SME sector in Saudi Arabia.

Note 3. The Ministry of Commerce and Investment (MOCI), which is the main regulator for business licenses and the supervising of companies in Saudi Arabia.

\section{Copyrights}

Copyright for this article is retained by the author(s), with first publication rights granted to the journal.

This is an open-access article distributed under the terms and conditions of the Creative Commons Attribution license (http://creativecommons.org/licenses/by/4.0/). 